\title{
OBITUARY
}

\section{The Rev. Gordon Matthews, M.A., B.Litt.}

The sudden death of Gordon Matthews from heart failure while fishing in Scotland on the 17th July of last year has stricken our School very grievously.

The son of Dr. Joseph Matthews, he was born at Liverpool on the 27th October, 1884. After education at the Merchant Taylors' School, Merton, and Mansfield, he received in 1909 ordination in the Congregational ministry, and offered himself to the London Missionary Society for service in India. A medical examination revealed that he had an "athlete's heart", and the Society therefore declined to confirm the appointment; but nevertheless he set out in 1910, under the Society's auspices, but on his own responsibility, and for four years worked at Salem, studying the speech and life of the Tamil people and carrying on pastoral labours among them. The next scene of his activities was Coimbatore, whither he was transferred in 1914, to serve as Vice-President in the London Missionary Society's High School until 1917, when he went out to Iraq as a Chaplain to the Forces. He returned in 1918 to Coimbatore ; then after a furlough lasting from 1920 to 1921 he was placed on the staff of the Madras Christian College as Professor of English, and discharged some important administrative duties with characteristic vigour and skill. Retiring from Indian service in 1939, he was appointed Lecturer in Tamil at the School of Oriental and African Studies, and speedily won the esteem and affection of his colleagues by his high qualities of heart and mind. As a teacher he was remarkably successful and inspiring, and his energies were not confined to this function, exacting though it was, for he likewise pursued his beloved studies in the abstruse ancient Tamil literature, leaving ready for publication an annotated translation of Meykaṇdar's Siva-ñanna-bōdham, a classic of Tamil Saiva theology, which it is hoped will be printed as soon as possible by the Forlong Fund.

He has left a widow, two sons, and a daughter, and to these his colleagues have offered their profound sympathy. Vale anima candida.

L. D. B. 


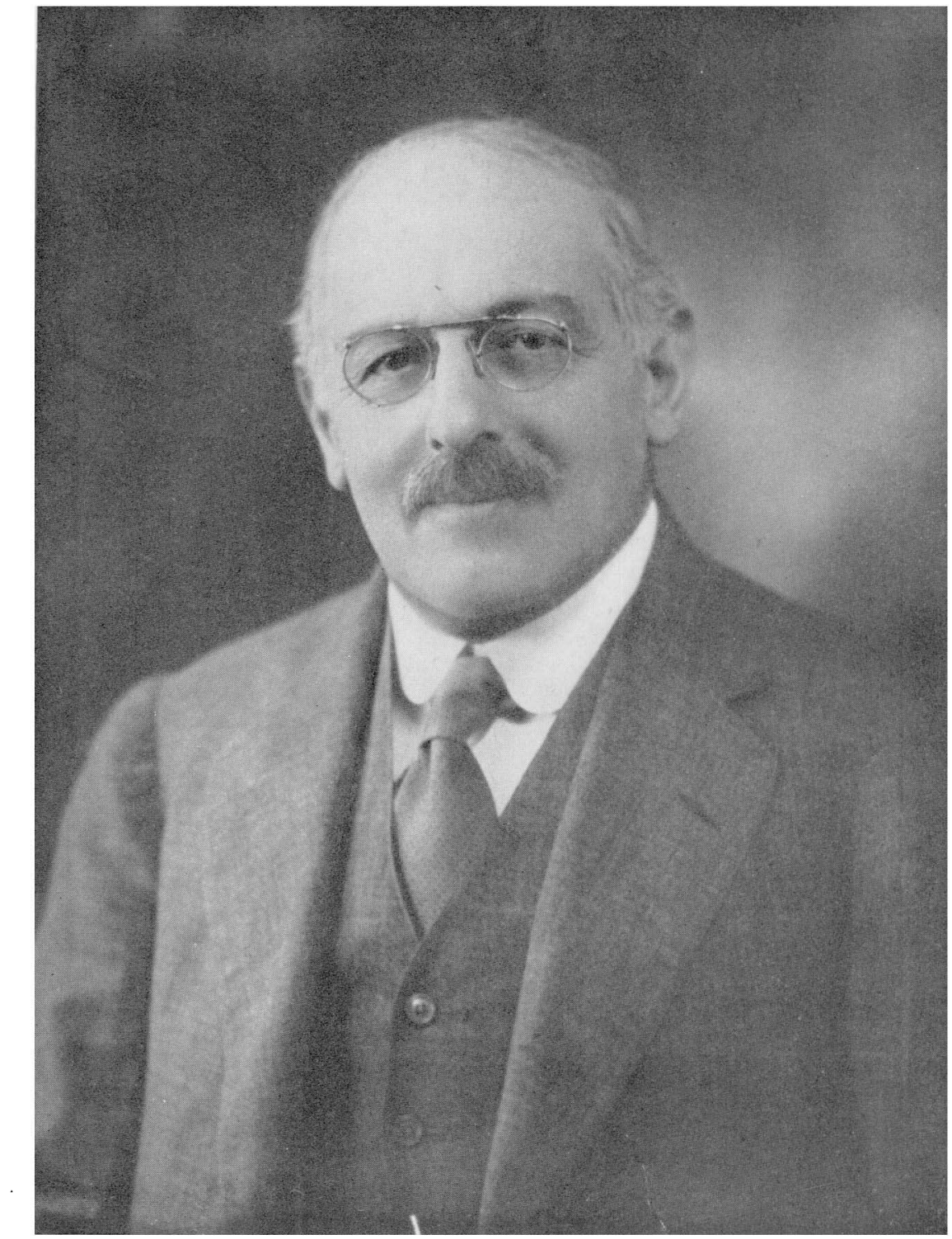

Sir Philir J. Hartog, K.B.E., C.I.E., LI.D., M.A., B.Sc.

Fecretary of the Lniversity of London Committee on Oriental Studies, 1905-6; of the Reay Committee, 1907-9; of the Cromer Committee, 1910-17; Honorary secretary of the sihool, 1916-17; Crown Member of the Goveming Body, 1916-46. 